\title{
Monitoring of toxic heavy metals contamination in commonly used Chinese materia medica
}

\author{
Mei-Yin Chien ${ }^{1} \cdot$ Chih-Min Yang ${ }^{1} \cdot$ Chih-Min Huang ${ }^{1} \cdot$ Chao-Hsiang Chen ${ }^{1,2} \mathbb{D}$
}

Received: 4 March 2020 / Accepted: 20 July 2020 / Published online: 27 July 2020

(c) Springer Nature Switzerland AG 2020

\begin{abstract}
Monitoring of toxic heavy metals (THMs) contamination, including lead ( $\mathrm{Pb}$ ), arsenic ( $\mathrm{As}$ ), cadmium (Cd), and mercury $(\mathrm{Hg})$, for the quality control in Chinese materia medica (CMM) is critical for ensuring safe medication use in the pharmaceutical industry. A validated inductively coupled plasma-mass spectrometry method was used to determine THMs content in 1887 samples for 27 selected types of commonly used CMM. The correlation coefficient of the calibration curves for four THMs was higher than 0.995 , indicating that the linearity is fine. The recovery rate was ranged in $82.6-105.4 \%$ for four THMs. The percentage of RSD in inter-day and intra-day precision test for four THMs was all lower than $10 \%$. The limit of quantitation in test solution for $\mathrm{Pb}, \mathrm{As}, \mathrm{Cd}$ and $\mathrm{Hg}$ was $0.212,0.500,0.038,0.044 \mu \mathrm{g} / \mathrm{L}$, indicating that this validated ICP-MS method exhibited excellent sensitivity. Among these THMs, $\mathrm{Pb}$ and $\mathrm{Cd}$ are the most abundant contaminants in 27 selected types of CMM. In diverse permissible limits (PL) established by different countries/organizations, Cinnamomi ramulus and Eucommiae cortex usually exceeded the PL of $0.3 \mu \mathrm{g} / \mathrm{g}$ for $\mathrm{Cd}$ and occasionally exceeded the PL of $5.0 \mu \mathrm{g} / \mathrm{g}$ for Pb. Chuanxiong rhizome seldom exceeded the PL of $1.0 \mu \mathrm{g} / \mathrm{g}$ for Cd. Eucommiae cortex, Raphani semen, Atractylodis macrocephalae rhizoma and Bupleuri radix occasionally exceeded the PL of $0.3 \mu \mathrm{g} / \mathrm{g}$ for $\mathrm{Cd}$. In conclusion, we hope to raise awareness of THMs contamination in commonly used CMM that affects safe medication use among farmers, manufacturer, and consumers.
\end{abstract}

Keywords Chinese materia medica $\cdot$ Inductively coupled plasma-mass spectrometry $\cdot$ Method validation · Permissible limit · Toxic heavy metals

\begin{tabular}{llll}
\multicolumn{2}{l}{ Abbreviations } & KF & Kochiae fructus \\
JF & Jujubae fructus & AF & Arctii fructus \\
AR & Astragali radix & CAS & Cassiae semen \\
HR & Hedysari radix & PS & Plantaginis semen \\
GRER & Glycyrrhizae radix et rhizome & BS & Benincasae semen \\
CIR & Cinnamomi ramulus & CHR & Chuanxiong rhizome \\
ASR & Angelicae sinensis radix & PAR & Paeoniae alba radix \\
CC & Cornu cervi & GR & Ginseng radix \\
RR & Rehmanniae radix & COR & Codonopsis radix \\
P & Poria & TCEP & Testudinis carapax et plastrum \\
RS & Raphani semen & CRP & Citri reticulatae pericarpium \\
CUS & Cuscutae semen & EC & Eucommiae cortex
\end{tabular}

These Mei-Yin Chien, Chih-Min Yang authors contributed equally to this work.

Chao-Hsiang Chen, cmy@koda.com.tw | ${ }^{1}$ Ko Da Pharmaceutical Co. Ltd., No.20-1, Gongye 3rd Rd., Pingzhen District, Taoyuan 324, Taiwan, ROC. ${ }^{2}$ Graduate Institute of Pharmacognosy, Taipei Medical University, Taipei, Taiwan. 


$\begin{array}{ll}\text { AMR } & \text { Atractylodis macrocephalae rhizome } \\ \text { BR } & \text { Bupleuri radix } \\ \text { SR } & \text { Scutellariae radix } \\ \text { AAS } & \text { Armeniacae amarum semen } \\ \text { THMs } & \text { Toxic heavy metals } \\ \text { Pb } & \text { Lead } \\ \mathrm{As} & \text { Arsenic } \\ \mathrm{Cd} & \text { Cadmium } \\ \mathrm{Hg} & \text { Mercury } \\ \mathrm{CMM} & \text { Chinese materia medica } \\ \mathrm{PL} & \text { Permissible limit } \\ \text { THP } & \text { Taiwan herbal pharmacopeia } \\ \mathrm{HKCMMS} & \text { Hong Kong Chinese materia medica } \\ & \text { standards } \\ \text { ICP-MS } & \text { Inductively coupled plasma mass } \\ & \text { spectrometry } \\ \text { ChP } & \text { Chinese pharmacopoeia } \\ \text { LOQ } & \text { Limit of quantitation } \\ \text { TFDA } & \text { Taiwan food and drug administration }\end{array}$

\section{Introduction}

Heavy metals are naturally existing elements widely distributed in our living environment and therefore can be absorbed into the human body through external sources, such as water, food, air, industrial waste, and chemical pollutants. Some toxic heavy metals (THMs), including lead $(\mathrm{Pb})$, arsenic $(\mathrm{As})$, cadmium $(\mathrm{Cd})$ and mercury $(\mathrm{Hg})$, can cause harmful health effects with extremely small amounts. As recommended by the Joint FAO/WHO Expert Committee for Food Additives (JECFA), the provisional tolerable weekly intake (PTWI) of $\mathrm{Pb}$, inorganic $\mathrm{As}, \mathrm{Cd}$ and $\mathrm{Hg}$ were set as $25 \mu \mathrm{g} / \mathrm{kg}$ body weight (BW) [1], $15 \mu \mathrm{g} / \mathrm{kg}$ BW [2], $7 \mu \mathrm{g} / \mathrm{kg}$ BW [3], and $5 \mu \mathrm{g} / \mathrm{kg}$ BW [1], respectively. The maximum tolerable intake for a $60-\mathrm{kg}$ healthy adult is $214 \mu \mathrm{g} / \mathrm{d}$ for Pb, $129 \mu \mathrm{g} / \mathrm{d}$ for inorganic As, $60 \mu \mathrm{g} / \mathrm{d}$ for $\mathrm{Cd}$ and $43 \mu \mathrm{g} / \mathrm{d}$ for $\mathrm{Hg}$ by calculation. THMs contamination in Chinese materia medica (CMM) can be attributed to its own properties, agricultural environment, and the processing method. For example, Cinnabaris and Realgar are red mercuric sulfate and arsenic sulfide mineral containing $\mathrm{Hg}$ and $\mathrm{As}$, respectively. In addition, contamination in soil and water and improper use of pesticides and fertilizers during cultivation as well as the use of containers or additives containing THMs during the processing step contributed to THMs contamination.

Several analytical techniques, including flame atomic absorption spectrometry, graphite furnace atomic absorption spectrometry, cold vapor atomic absorption spectrometry, atomic fluorescence spectrometry, high-performance liquid chromatography, inductively coupled plasma (ICP) optical emission spectrometry or mass spectrometry
(MS), X-ray fluorescence spectrometry, differential pulse polarography, neutron activation analysis, and anodic stripping voltammetry, have been used to determine heavy metals content in natural products or herbal products [4]. ICP-MS is one of the most sophisticated analytical instrumentation with the advantage of multi-elemental character, low limits of detection, wide dynamic range, etc. Several national pharmacopeias, including Taiwan Herbal Pharmacopeia (THP), Hong Kong Chinese Materia Medica Standards (HKCMMS) and Chinese Pharmacopoeia (ChP), have recommended ICP-MS as the analytical method to determine THMs content in CMM for ensuring the safety of pharmaceutical products. In this study, THMs content, including $\mathrm{Pb}, \mathrm{As}, \mathrm{Cd}$, and $\mathrm{Hg}$, was determined in 1887 samples for 27 selected types of CMM using nitric acid and microwave digestion followed by a validated ICP-MS method. The microwave was used for the CMM samples digestion because it exhibited better accuracy in relation to both time and recovery rate [5]. Based on the $\mathrm{ICH}$ Q2(R1), the validation items included linearity, accuracy (recovery rate), inter-day and intra-day precision, method detection limit (MDL) and limit of quantitation (LOQ) [6].

\section{Materials and methods}

\subsection{CMM samples collection}

A total of 1,887 samples for the 27 types of selected CMM were purchased from different provinces of China and chosen according to the top 20 imported CMM between 2016 and 2018. The imported quantities of the CMM were retrieved by the department of Chinese Medicine and Pharmacy, Ministry of Health and Welfare (Taipei, Taiwan), as indicated in Table 1. It should be noted that the sum of imported quantities of Astragali radix (AR) and Hedysari radix (HR) is ranked second. In addition, the sum of imported quantities of seven CMM, including Raphani semen (RS), Cuscutae semen (CUS), Kochiae fructus (KF), Arctii fructus (AF), Cassiae semen (CAS), Plantaginis semen (PS) and Benincasae semen (BS), is ranked ninth.

\subsection{Preparation of analytical sample solution}

All CMM were ground into powder using pulverizer followed by passing through a 40-mesh filter. Briefly, $0.2 \mathrm{~g}$ of each sample powder was placed into a microwave digestion tube with $6 \mathrm{~mL}$ of concentrated nitric acid and $1.5 \mathrm{~mL}$ of hydrogen peroxide solution for $20 \mathrm{~min}$. The sample solution was digested using MARS microwaveaccelerated reaction system (MARS Xpress, CEM, USA). Digestion parameters for the microwave system were set as $1,600 \mathrm{~W}$ for microwave, $30 \mathrm{~min}$ for ramp time, $205^{\circ} \mathrm{C}$ 


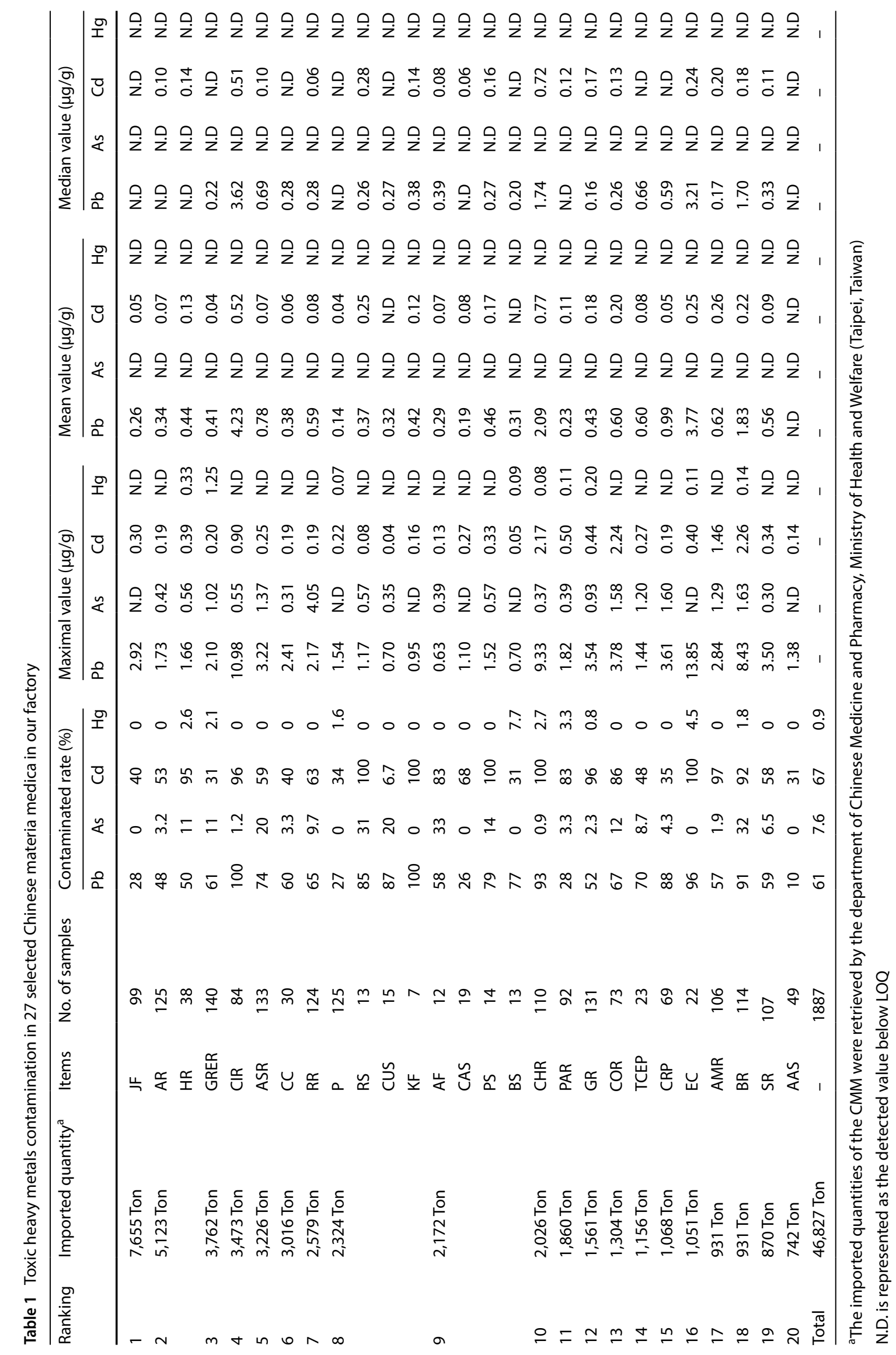


for temperature, and $20 \mathrm{~min}$ for hold time. After digestion, $1 \mathrm{~mL}$ of internal stock standard solution was added to deionized water to produce a final volume of $100 \mathrm{~mL}$ followed by passing through a $0.45-\mu \mathrm{m}$ filter to obtain the analytical sample solution.

\subsection{Preparation of standard solution}

One thousand $\mu \mathrm{g} / \mathrm{mL}$ of $\mathrm{Pb}, \mathrm{As}, \mathrm{Cd}, \mathrm{Hg}$, rhodium (Rh), and gold $(\mathrm{Au})$ standard solution was purchased from SigmaAldrich (St. Louis MO, USA). The external standard stock solution I containing $10 \mu \mathrm{g} / \mathrm{mL}$ of Pb and As and $1 \mu \mathrm{g} / \mathrm{mL}$ of $\mathrm{Cd}$ and $\mathrm{Hg}$ was prepared by adding $1 \mathrm{~mL}$ of $1,000 \mu \mathrm{g} /$ $\mathrm{mL}$ of $\mathrm{Pb}$ and $\mathrm{As}$ standard solution and $0.1 \mathrm{~mL}$ of $1,000 \mu \mathrm{g} /$ $\mathrm{mL}$ of $\mathrm{Cd}$ and $\mathrm{Hg}$ standard solution to $1 \%(\mathrm{v} / \mathrm{v})$ nitric acid solution to produce a final volume of $100 \mathrm{~mL}$. The external standard stock solution II containing $1 \mu \mathrm{g} / \mathrm{mL}$ of $\mathrm{Pb}$ and As and $0.1 \mu \mathrm{g} / \mathrm{mL}$ of $\mathrm{Cd}$ and $\mathrm{Hg}$ was prepared by adding $1 \mathrm{~mL}$ of external stock standard solution I to $1 \%(\mathrm{v} / \mathrm{v})$ nitric acid solution to produce a final volume of $10 \mathrm{~mL}$. The internal standard stock solution consisting $1 \mu \mathrm{g} / \mathrm{mL}$ of Rh and $10 \mu \mathrm{g} / \mathrm{mL}$ of Au was prepared by combining $0.1 \mathrm{~mL}$ of $1000 \mu \mathrm{g} / \mathrm{mL}$ of Rh and $1 \mathrm{~mL}$ of $1000 \mu \mathrm{g} / \mathrm{mL}$ of Au standard solution to $1 \%(\mathrm{v} / \mathrm{v})$ nitric acid solution to produce a final volume of $100 \mathrm{~mL}$. Standard working solution containing $0.2-50 \mu \mathrm{g} / \mathrm{L}$ of Pb and As, $0.02-5 \mu \mathrm{g} / \mathrm{L}$ of $\mathrm{Cd}$ and $\mathrm{Hg}$, $10 \mu \mathrm{g} / \mathrm{L}$ of Rh and $100 \mu \mathrm{g} / \mathrm{L}$ of Au was made by combining different volumes $(10,50,250,1000$ and $2500 \mu \mathrm{L})$ of the external standard stock solution II to $500 \mu \mathrm{L}$ of internal standard stock solution diluted in $1 \%(\mathrm{v} / \mathrm{v})$ nitric acid to a final volume of $50 \mathrm{~mL}$.

\subsection{ICP-MS condition}

A PerkinElmerNexIONTM300X ICP-MS (MA, USA) was used for simultaneous detection of $\mathrm{Pb}, \mathrm{As}, \mathrm{Cd}$ and $\mathrm{Hg}$ content in CMM. The setting of the ICP-MS condition was established as the followings: plasma power $1500 \mathrm{~W}$, carrier gas $\mathrm{Ar}$, plasma gas flow $18 \mathrm{~L} / \mathrm{min}$, auxiliary gas flow $1.2 \mathrm{~L} / \mathrm{min}$ and nebulizer gas flow $1.1 \mathrm{~L} / \mathrm{min}$. The $\mathrm{m} / \mathrm{z}$ ratios for the four THMs were set as ${ }^{208} \mathrm{~Pb},{ }^{75} \mathrm{As},{ }^{111} \mathrm{Cd}$ and ${ }^{202} \mathrm{Hg}$.

\subsection{Method validation}

The linearity of the calibration curves for the four THMs was established using five different concentrations (0.2-50 $\mu \mathrm{g} / \mathrm{L}$ for $\mathrm{Pb}$ and As and $0.02-5 \mu \mathrm{g} / \mathrm{L}$ for $\mathrm{Cd}$ and $\mathrm{Hg}$ ) in triplicates for each concentration. The intercept, slope of the regression line and the correlation coefficient were recorded. The values of correlation coefficient for the four THMs should be higher than 0.995. For accuracy, free-THMs samples were spiked with low $(4.0 \mu \mathrm{g} / \mathrm{mL}$ for $\mathrm{Pb}$ and $\mathrm{As}$ and $0.4 \mu \mathrm{g} / \mathrm{mL}$ for $\mathrm{Cd}$ and $\mathrm{Hg}$ ), medium $(5.0 \mu \mathrm{g} / \mathrm{mL}$ for $\mathrm{Pb}$ and $\mathrm{As}$ and $0.5 \mu \mathrm{g} / \mathrm{mL}$ for $\mathrm{Cd}$ and $\mathrm{Hg})$ and high $(6.0 \mu \mathrm{g} / \mathrm{mL}$ for $\mathrm{Pb}$ and $\mathrm{As}$ and $0.6 \mu \mathrm{g} / \mathrm{mL}$ for $\mathrm{Cd}$ and $\mathrm{Hg}$ ) concentrations of the four THMs followed by nitric acid and microwave digestion in triplicates. The recovery rate was calculated as (detection value $\div$ spike value) $\times 100 \%$, and the detection value has been subtracted the elemental background from matrix. An acceptable quality level of recovery rate should be ranged in $75-120 \%$. For inter-day and intra-day precision, free-THMs samples were spiked with $5.0 \mu \mathrm{g} / \mathrm{mL}$ for $\mathrm{Pb}$ and As and $0.5 \mu \mathrm{g} / \mathrm{mL}$ for $\mathrm{Cd}$ and $\mathrm{Hg}$ of the four THMs followed by nitric acid and microwave digestion in six times. The percentage of relative standard deviation (RSD) was calculated as follows: (SD value $\div$ mean value) $\times 100 \%$, and the calculated value should be lower than $10 \%$. For determining $M D L$ and $L O Q$, the calibration curves for the four THMs were established using relative low different concentrations $(0.01-1.0 \mu \mathrm{g} / \mathrm{L}$ for $\mathrm{Pb}, 0.01-5.0 \mu \mathrm{g} / \mathrm{L}$ for As and $0.01-2.0 \mu \mathrm{g} / \mathrm{L}$ for $(\mathrm{d}$ and $\mathrm{Hg}$ ). Test solution containing $0.4 \mu \mathrm{g} / \mathrm{L}$ for $\mathrm{Pb}, 1 \mu \mathrm{g} / \mathrm{L}$ for As and $0.1 \mu \mathrm{g} / \mathrm{L}$ for $\mathrm{Cd}$ and $\mathrm{Hg}$ was carried out in seven times. The slope of calibration curves for the four THMs was recorded. The standard deviation (SD) in ratio of intensities between standard and internal standard for seven times determination was calculated. The MDL and $\mathrm{LOQ}$ were calculated as $3.3 \times \mathrm{SD} \div$ slope and $10 \times \mathrm{SD} \div$ slope, respectively.

\section{Results and discussion}

\subsection{Method validation}

The definition of validation is the action of checking or proving the validity or accuracy of developed experimental method. Evaluation by ICP-MS method was validated by assessing the correlation coefficient, accuracy (recovery rate), inter-day, and intra-day precision, MDL, and LOQ. The correlation coefficient of the calibration curves for the four THMs were all higher than 0.995, indicating that the linearity is fine (Table 2). THMs determination by ICP-MS is known to be interfered by spectral and nonspectral interferences. This interference might affect the low recovery of THMs. For example, the determination of As ( $\mathrm{m} / \mathrm{z} 75)$ by ICP-MS can be interfered by $\mathrm{ArCl}^{+}(\mathrm{m} / \mathrm{z} 75)$, polyatomic species. Herein, we used dynamic reaction cell (DRC) technology to solve this interference. DRC technology features a scanning quadrupole that removes all interferences created by reactions in the Universal Cell, which enables any reactive gas to be used. By optimizing the cell's quadrupole conditions, only the element of interest is allowed to pass through to the analyzing quadrupole. It is well recognized that ion-molecule reaction chemistry offers the best performance for the reduction of complex polyatomic spectral interference [7]. The recovery rate was 

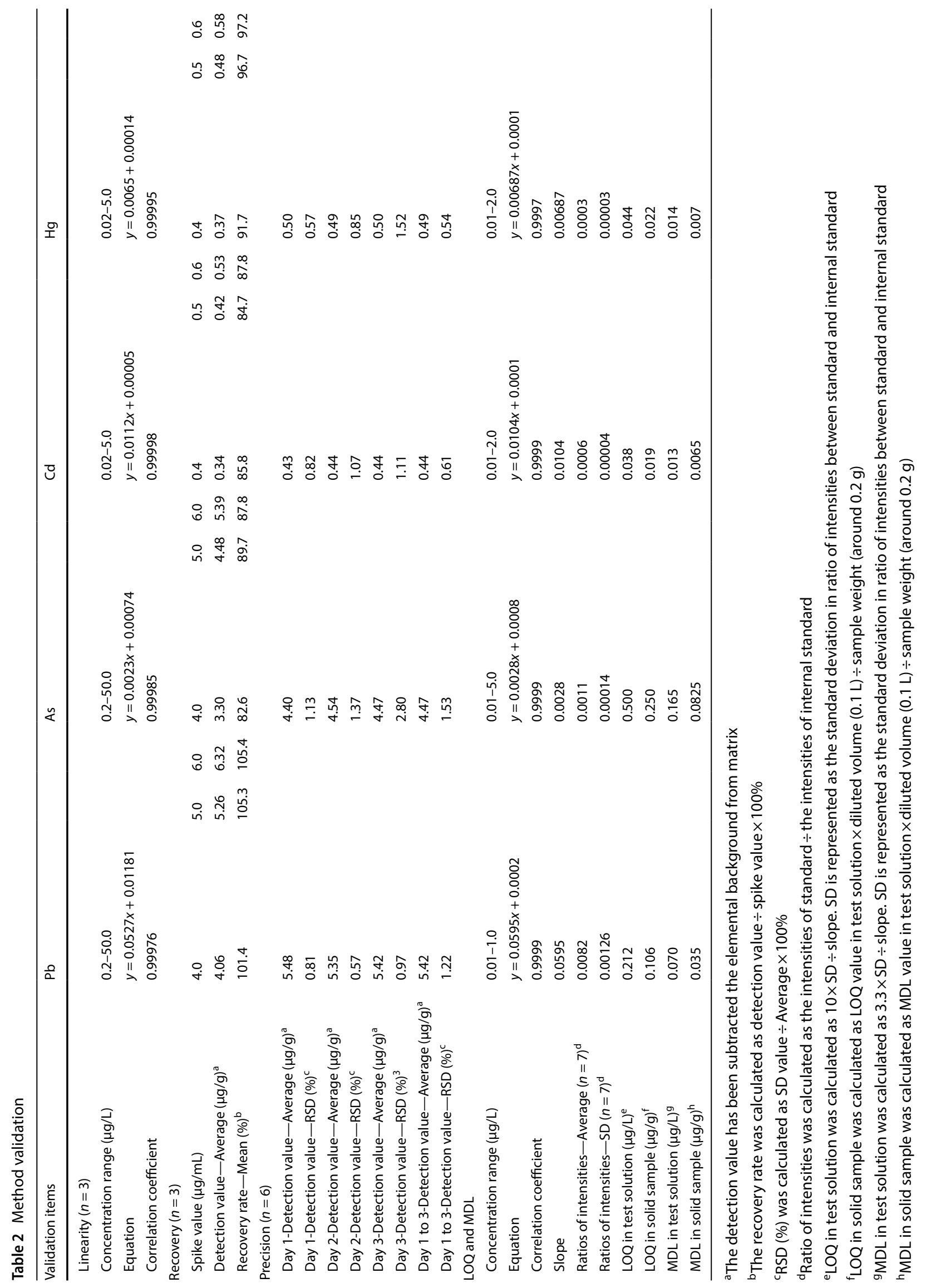
in the range of $101.4-105.4 \%$ for $\mathrm{Pb}, 82.6-89.7 \%$ for $\mathrm{As}$, 84.7-87.8\% for $\mathrm{Cd}$ and $91.7-97.2 \%$ for $\mathrm{Hg}$ which meet the acceptable quality level of $75-120 \%$ (Table 2 ). The precision is the condition where the results from independent test are acquired with the same method on the same sample in the same or different day by the same or different operator for several replicates using the same analytical instrument [7]. The calculated RSD (\%) in inter-day and intra-day precision for the four THMs in spiked samples was all lower than $10 \%$ (Table 2). The LOQ in test solution for $\mathrm{Pb}, \mathrm{As}, \mathrm{Cd}$ and $\mathrm{Hg}$ was $0.212,0.500,0.038,0.044 \mu \mathrm{g} / \mathrm{L}$, respectively, and in solid samples was $0.106,0.250,0.019$, $0.022 \mu \mathrm{g} / \mathrm{g}$, respectively (Table 2). The MDL in test solution for $\mathrm{Pb}, \mathrm{As}, \mathrm{Cd}$ and $\mathrm{Hg}$ was $0.070,0.165,0.013,0.014 \mu \mathrm{g} / \mathrm{L}$, respectively, and in solid samples was $0.035,0.0825$, $0.0065,0.007 \mu \mathrm{g} / \mathrm{g}$, respectively (Table 2 ). Results obtained from LOQ and MDL indicated that this validated ICP-MS method exhibited excellent sensitivity.

\subsection{Monitoring of THMs contamination in selected CMM}

CMM has been regarded as a potential source of THMs toxicity, including $\mathrm{Pb}, \mathrm{As}, \mathrm{Cd}$ and $\mathrm{Hg}$, to human and animals [8]. WHO has also recommended that CMM and its products should be determined for the presence of THMs [9]. Herein, an ICP-MS method was used to determine THMs content in a total of 1,887 samples for the 27 selected types of CMM. The maximal, average and median values of all CMM for four THMs are shown in Table 1. Pb was detected in 1,145 samples out of the total samples with the contaminated rate of $61 \%$ (Table 1). Among these $\mathrm{Pb}$-contaminated CMM, Cinnamomi ramulus (CIR), $\mathrm{RS}, \mathrm{CUS}, \mathrm{KF}$, Chuanxiong rhizome (CHR), Citri reticulatae pericarpium (CRP), Eucommiae cortex (EC) and Bupleuri radix $(\mathrm{BR})$ are most commonly contaminated by $\mathrm{Pb}$ with the contaminated rate higher than $80 \%$ (Table 1). A total of $7(6.4 \%)$ and $4(3.5 \%)$ samples in $C H R$ and $B R$, respectively, exceeded the PL of $5.0 \mu \mathrm{g} / \mathrm{g}$ for $\mathrm{Pb}$ as established by THP and HKCMMS (Table 4). In addition to CHR and BR, a total of $27(32 \%)$ and 4 (18\%) samples in CIR and EC, respectively, exceeded the $\mathrm{PL}$ of $5.0 \mathrm{\mu g} / \mathrm{g}$ for $\mathrm{Pb}$ as established by HKCMMS (Table 4). However, only $1(1.2 \%)$ and 2 (9.1\%) samples in CIR and EC, respectively, exceeded the PL of $10.0 \mu \mathrm{g} / \mathrm{g}$ for $\mathrm{Pb}$ as established by $\mathrm{WHO}$ and ISO18664:2015 (Table 4).

Moreover, As was detected in 143 samples out of the total samples with the contaminated rate of $7.6 \%$ (Table 1). $\mathrm{RS}, \mathrm{AF}$ and $\mathrm{BR}$ are seldom contaminated by As with the contaminated higher than $30 \%$ (Table 1). None of the samples exceeded the PL of 3.0 or $5.0 \mu \mathrm{g} / \mathrm{g}$ as set by THP (Table 4). Similarly, none of the samples exceeded the PL of 2.0 or $5.0 \mu \mathrm{g} / \mathrm{g}$ as set by Japanese Pharmacopeia (JP)
(Table 4). Only 3 (2.4\%), 2 (1.6\%) and 1 (0.8\%) samples in Rehmanniae radix (RR) exceeded the PL of $2.0 \mu \mathrm{g} / \mathrm{g}$ and $4.0 \mu \mathrm{g} / \mathrm{g}$, respectively, as set by HKCMMS and ISO18664:2015, respectively (Table 4).

Furthermore, $\mathrm{Cd}$ was detected in 1,257 samples out of the total samples with the contaminated rate of $67 \%$ (Table 1). Nearly half of all CMM, including HR, CIR, RS, $\mathrm{KF}, \mathrm{AF}, \mathrm{PS}, \mathrm{CHR}$, Paeoniae alba radix (PAR), Ginseng radix (GR), Codonopsis radix (COR), EC, Armeniacae amarum semen (AMR) and BR, are most commonly contaminated by $\mathrm{Cd}$ with contaminated rate higher than $80 \%$ (Table 1 ). Only $1(2.6 \%)$ sample in HR and $1(1.1 \%)$ sample in PAR exceeded the PL of $0.3 \mu \mathrm{g} / \mathrm{g}$ for $\mathrm{Cd}$ as formulated by THP and HKCMMS (Table 4). Among the 27 selected CMM, the ChP only regulated the PL for THMs in AR, Glycyrrhizae radix et rhizoma (GRER) and PAR (Table 3). Similarly, only $1(1.1 \%)$ sample in PAR exceeded the PL of $0.3 \mu \mathrm{g} / \mathrm{g}$ for $\mathrm{Cd}$ as formulated by ChP (Table 4). A total of $2(2.7 \%), 19$ (17\%), $1(0.9 \%)$ and $2(1.8 \%)$ samples in COR, CHR, AMR and BR, respectively, exceeded the PL of $1.0 \mu \mathrm{g} / \mathrm{g}$ for $\mathrm{Cd}$ as formulated by THP and HKCMMS (Table 4). Under the $\mathrm{PL}$ of $0.3 \mu \mathrm{g} / \mathrm{g}$ for $\mathrm{Cd}$ as formulated by WHO, a total of 74 and 108 samples in CIR and CHR, respectively, with the exceeding rate was $88 \%$ and $98 \%$, respectively (Table 4 ). Also, the exceeding rate in RS, EC, AMR and BR was ranged from $10 \%$ to $30 \%$ (Table 4 ). In addition, the exceeding rate in other $\mathrm{Cd}$-contaminated $\mathrm{CMM}$, including Jujubae fructus (JF), HR, PS, PAR, GR, COR and Scutellariae radix (SR), was lower than $10 \%$ (Table 4). Only 1 (0.9\%) sample in CHR and $1(0.9 \%)$ sample in BR exceeded the PL of $2.0 \mu \mathrm{g} / \mathrm{g}$ for $\mathrm{Cd}$ as formulated by ISO 18664:2015 (Table 4).

Likewise, $\mathrm{Hg}$ was detected in 17 (0.9\%) samples out of the total samples (Table 1). The contaminated rate for $\mathrm{Hg}$ in all selected CMM was not higher than 10\% (Table 1). Only $1(0.7 \%)$ sample in GRER exceeded the PL of $0.2 \mu \mathrm{g} / \mathrm{g}$ for $\mathrm{Hg}$ as regulated by THP, ChP and HKCMMS (Table 4). Similarly, only 1 (2.6\%) sample in HR exceeded the PL of $0.2 \mu \mathrm{g} / \mathrm{g}$ for $\mathrm{Hg}$ as regulated by THP and HKCMMS (Table 4).

\subsection{Comparison of PL among different countries/ organizations}

As shown in Table 3, we further summarized the PL set by different countries/organizations for the four THMs of the all selected CMM. The Taiwan authority has renewed the PL for the four THMs in 355 types of CMM in 2016 and brought it into the THP [10]. The general rules of the PL in THP were established as 5.0, 3.0, 1.0, and $0.2 \mu \mathrm{g} / \mathrm{g}$ for $\mathrm{Pb}$, As, $\mathrm{Cd}$, and $\mathrm{Hg}$, respectively, in most CMM [10]. For specific CMM, the PL was $10.0 \mu \mathrm{g} / \mathrm{g}$ in CUS or $15.0 \mu \mathrm{g} / \mathrm{g}$ in CIR and $\mathrm{EC}$ for $\mathrm{Pb}, 5.0 \mu \mathrm{g} / \mathrm{g}$ in ASR, RR, Poria (P), CHR, AMR, BR and SR for As, $0.3 \mu \mathrm{g} / \mathrm{g}$ in AR, HR, GRER and PAR or $1.5 \mu \mathrm{g} / \mathrm{g}$ for $\mathrm{Cd}$ and $0.5 \mu \mathrm{g} / \mathrm{g}$ for $\mathrm{Hg}$ (Table 3) [10]. The ChP has drawn 
Table 3 The permissible limit of $\mathrm{Pb}, \mathrm{As}, \mathrm{Cd}$, and $\mathrm{Hg}$ for 27 selected types of Chinese materia medica in different countries/organizations
Table 4 The percentage of Chinese materia medica exceeding permissible limits in different countries/ organizations

\begin{tabular}{|c|c|c|c|c|c|}
\hline \multirow[t]{2}{*}{ Countries/organizations } & \multicolumn{4}{|c|}{$\begin{array}{l}\text { Permissible limit } \\
(\mu \mathrm{g} / \mathrm{g})\end{array}$} & \multirow[t]{2}{*}{ CMM } \\
\hline & $\mathrm{Pb}$ & As & $\mathrm{Cd}$ & $\mathrm{Hg}$ & \\
\hline \multirow[t]{6}{*}{ Taiwan $^{a}$} & 5.0 & 3.0 & 1.0 & 0.2 & JF, CC, RS, KF, AF, CAS, PS, BS, GR, COR, TECP, CRP, AAS \\
\hline & 5.0 & 3.0 & 0.3 & 0.2 & AR, HR, GRER \\
\hline & 15.0 & 3.0 & 1.0 & 0.2 & CIR, EC \\
\hline & 5.0 & 5.0 & 1.0 & 0.2 & ASR, RR, P, CHR, AMR, BR, SR \\
\hline & 10.0 & 3.0 & 1.0 & 0.2 & CUS \\
\hline & 5.0 & 5.0 & 0.3 & 0.2 & PAR \\
\hline \multirow[t]{2}{*}{$J^{\prime a p a n}{ }^{b}$} & N/A & 5.0 & $\mathrm{~N} / \mathrm{A}$ & $\mathrm{N} / \mathrm{A}$ & AR, GRER, ASR, RR, P, BR, SR \\
\hline & N/A & 2.0 & N/A & $\mathrm{N} / \mathrm{A}$ & GR \\
\hline China $^{c}$ & 5.0 & 2.0 & 0.3 & 0.2 & AR, GRER, PAR \\
\hline Hong Kong ${ }^{d}$ & 5.0 & 2.0 & 1.0 & 0.2 & $\begin{array}{l}\text { AR, HR, GRER, CIR, ASR, RR, CUS, KF, AF, CAS, PS, CHR, } \\
\text { PAR, GR, COR, CRP, EC, AMR, BR, SR }\end{array}$ \\
\hline $\mathrm{WHO}^{\mathrm{e}}$ & 10.0 & $\mathrm{~N} / \mathrm{A}$ & 0.3 & $\mathrm{~N} / \mathrm{A}$ & 25 selected types of CMM (CC and TCEP excluded) \\
\hline ISO $^{f}$ & 10.0 & 4.0 & 2.0 & 3.0 & 27 selected types of $\mathrm{CMM}$ \\
\hline
\end{tabular}

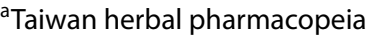

bJapanese pharmacopeia

${ }^{c}$ Chinese pharmacopoeia

${ }^{\mathrm{d}}$ Hong Kong Chinese materia medica standards

eWorld Health Organization

fISO18664:2015

\begin{tabular}{|c|c|c|c|c|c|c|c|c|c|c|c|c|c|c|}
\hline \multicolumn{15}{|c|}{ Percentage of samples exceeding permissible limits (\%) } \\
\hline \multirow[b]{2}{*}{ CMM } & \multicolumn{3}{|c|}{ Taiwan $^{\mathrm{a}}$} & \multicolumn{2}{|c|}{ China $^{\mathrm{b}}$} & \multicolumn{4}{|c|}{ Hong Kong ${ }^{c}$} & \multicolumn{2}{|c|}{$\mathrm{WHO}^{\mathrm{d}}$} & \multicolumn{3}{|c|}{$\mathrm{ISO}^{\mathrm{e}}$} \\
\hline & $\mathrm{Pb}$ & $\mathrm{Cd}$ & $\mathrm{Hg}$ & $\mathrm{Cd}$ & $\mathrm{Hg}$ & $\mathrm{Pb}$ & As & $\mathrm{Cd}$ & $\mathrm{Hg}$ & $\mathrm{Pb}$ & $\mathrm{Cd}$ & $\mathrm{Pb}$ & As & $\mathrm{Cd}$ \\
\hline JF & - & - & - & - & - & - & - & - & - & - & 1.0 & - & - & - \\
\hline $\mathrm{HR}$ & - & 2.6 & 2.6 & - & - & - & - & 2.6 & 2.6 & - & 2.6 & - & - & - \\
\hline GRER & - & - & 0.7 & - & 0.7 & - & - & - & 0.7 & - & - & - & - & - \\
\hline CIR & - & - & - & - & - & 32 & - & - & - & 1.2 & 88 & 1.2 & - & - \\
\hline $\mathrm{RR}$ & - & - & - & - & - & - & 2.4 & - & - & - & - & - & 0.8 & - \\
\hline $\mathrm{RS}$ & - & - & - & - & - & - & - & - & - & - & 23 & - & - & - \\
\hline PS & - & - & - & - & - & - & - & - & - & - & 7.1 & - & - & - \\
\hline CHR & 6.4 & 17 & - & - & - & 6.4 & - & 17 & - & - & 98 & - & - & 0.9 \\
\hline PAR & - & 1.1 & - & 1.1 & - & - & - & - & - & - & 1.1 & - & - & - \\
\hline GR & - & - & - & - & - & - & - & - & - & - & 8.4 & - & - & - \\
\hline COR & - & 2.7 & - & - & - & - & - & 2.7 & - & - & 9.6 & - & - & - \\
\hline $\mathrm{EC}$ & - & - & - & - & - & 18 & - & - & - & 9.1 & 23 & 9.1 & - & - \\
\hline AMR & - & 0.9 & - & - & - & - & - & 0.9 & - & - & 33 & - & - & - \\
\hline BR & 3.5 & 1.8 & - & - & - & 3.5 & - & 1.8 & - & - & 13 & - & - & 0.9 \\
\hline SR & - & - & - & - & - & - & - & - & - & - & 2.8 & - & - & - \\
\hline
\end{tabular}

aTaiwan Herbal Pharmacopeia

${ }^{\mathrm{b}}$ Chinese Pharmacopoeia

'Hong Kong Chinese Materia Medica Standards

${ }^{\mathrm{d}}$ World Health organization

eISO18664:2015 
up the PL of 5.0, 2.0, 0.3 and $0.2 \mu \mathrm{g} / \mathrm{g}$ for $\mathrm{Pb}, \mathrm{As}, \mathrm{Cd}$ and $\mathrm{Hg}$, respectively, in eleven types of CMM, whereas, the PLs were varied in some specific CMM [11]. Herein, only AR, GRER and PAR were included (Table 3). The JP only proposed the PL of 2.0 or $5.0 \mu \mathrm{g} / \mathrm{g}$ for As in certain CMM [12]. The PL for As was $2.0 \mu \mathrm{g} / \mathrm{g}$ in GR and $5.0 \mu \mathrm{g} / \mathrm{g}$ in $A R$, GRER, ASR, RR, P, BR and SR (Table 3). The nine volumes of HKCMMS covering standards for a total of 299 CMM have been published. The PL of 5.0, 2.0, 1.0 and $0.2 \mu \mathrm{g} / \mathrm{g}$ for $\mathrm{Pb}$, $\mathrm{As}, \mathrm{Cd}$ and $\mathrm{Hg}$, respectively, as a general rule in most CMM [13]. The WHO only recommended the PL of $10.0 \mu \mathrm{g} / \mathrm{g}$ for $\mathrm{Pb}$ and $0.3 \mu \mathrm{g} / \mathrm{g}$ for $\mathrm{Cd}$ in dried plant materials [14]. The International Organization for Standardization (ISO) also released ISO 18,664:2015 and published the PL of 10.0, 4.0, 2.0 , and $3.0 \mu \mathrm{g} / \mathrm{g}$ for $\mathrm{Pb}, \mathrm{As}, \mathrm{Cd}$, and $\mathrm{Hg}$, respectively, in all CMM except minerals [15].

Taking CIR for example, the PL of 15.0, 5.0 and $10 \mu \mathrm{g} / \mathrm{g}$ for $\mathrm{Pb}$ has been established by THP, HKCMMS and WHO, respectively, with the exceeding rate of $0 \%, 32 \%$ and $1.2 \%$, respectively (Table 4). The PL of 1.0 and $0.3 \mu \mathrm{g} / \mathrm{g}$ for $\mathrm{Cd}$ in $\mathrm{CIR}$ has been set by THP and WHO, respectively, with the exceeding rate of $0 \%$ and $88 \%$ (Table 4 ). Another example is CHR. Similarly, the PL of 1.0 and $0.3 \mu \mathrm{g} / \mathrm{g}$ for $\mathrm{Cd}$ has been drawn up by THP and WHO, respectively, with the exceeding rate of $27 \%$ and $98 \%$, respectively (Table 4 ). The diverse $\mathrm{PL}$ for the four THMs set by various countries/organizations is the major reason for the difference in the exceeding rate in CMM. As compared to other countries/organizations, the THP did set a more practical and reasonable PL. The THP established the PL for the four THMs based on the inspection data collected from several certificated Chinese herbal medicine pharmaceutical factories in Taiwan and on the 80th percentile values of the Taiwan Food and Drug Administration (TFDA) surveys from 2006 to 2013 [16-23] as well as referred to the PL established by other countries/ organizations. There is an increasing number of people worldwide using CMM as remedy, health food and dietary supplements, therefore, it is necessary to establish the unifying PL for THMs in CMM. One limitation existed that no clear correlation was found between the levels of THMs in soil and collection site in CMM because our CMM samples were collected from herbal markets or imported from trading agent in different provinces of China. It should also be noted that the present results did not represent the exact quality of the CMM sold in Taiwan and our company only imported the qualified CMM.

\section{Conclusions}

This study provides insights into THMs, including $\mathrm{Pb}, \mathrm{As}$, $\mathrm{Cd}$ and $\mathrm{Hg}$, contamination in the imported 27 types of selected CMM. Overall, $\mathrm{Pb}$ and $\mathrm{Cd}$ are the most abundant contaminant in selected CMM. In diverse permissible limits $(\mathrm{PL})$ established by different countries/organizations, CIR and EC usually exceeded the PL of $0.3 \mu \mathrm{g} / \mathrm{g}$ for $\mathrm{Cd}$ and occasionally exceeded the PL of $5.0 \mu \mathrm{g} / \mathrm{g}$ for $\mathrm{Pb}$. CHR seldom exceeded the PL of $1.0 \mu \mathrm{g} / \mathrm{g}$ for Cd. EC, RS, AMR, and BR occasionally exceeded the PL of $0.3 \mu \mathrm{g} / \mathrm{g}$ for $\mathrm{Cd}$. We hope to raise awareness of THMs contamination in CMM that affects safe medication use among farmers, manufacturer and consumers.

Author contributions Dr. Mei-Yin Chien and Dr. Chao-Hsiang Chen were involved in conception and design of study. Dr. Chih-Min Yang and Dr. Chih-Min Huang were involved in acquisition of data. Dr. MeiYin Chien, Dr. Chih-Min Yang and Dr. Chih-Min Huang were involved in analysis and interpretation of data. Dr. Mei-Yin Chien was involved in drafting the manuscript. Dr. Chao-Hsiang Chen was involved in revising the manuscript critically for important intellectual content. Dr. Mei-Yin Chien, Dr. Chih-Min Yang, Dr. Chih-Min Huang and Dr. Chao-Hsiang Chen were involved in approval of the version of the manuscript to be published.

\section{Compliance with ethical standards}

Conflicts of interest All authors listed in this study from our company and the results obtained from the present study were part of the quality control process in our company. Therefore, we declare that there is no conflict of interests.

\section{References}

1. World Health Organization and Food and Agriculture Organization of the United Nations (1993) Evaluation of certain food additives and contaminants. Forty-first report of the Joint FAO/ WHO Expert Committee on Food Additives. Geneva, Switzerland: World Health Organization.

2. World Health Organization and Food and Agriculture Organization of the United Nations (1989) Evaluation of certain food additives and contaminants. Thirty-third report of the Joint FAO/ WHO Expert Committee on Food Additives. Geneva, Switzerland: World Health Organization.

3. World Health Organization and Food and Agriculture Organization of the United Nations (2003) Evaluation of certain food additives and contaminants. Sixty-first report of the Joint FAO/ WHO Expert Committee on Food Additives. Rome, Italy: World Health Organization. 2003.

4. Yuan X, Chapman RL, Wu Z (2011) Analytical methods for heavy metals in herbal medicines. Phytochem Anal 22:189-198

5. Sesli E, Tuzen M, Soylak M (2008) Evaluation of trace metal contents of some wild edible mushrooms from Black sea region, Turkey. J Hazard Mater 160:462-467

6. International Conference on Harmonisation of Technical Requirements for Registration of Pharmaceutical for Human Use (2005) Validation of Analytical Procedures: Text and Methodology Q2(R1), ICH Harmonised Tripartite Guideline.

7. D'llio S, Majorani C, Petrucci F, Violante N, Senofonte O (2010) Method validation for the quantification of $\mathrm{As}, \mathrm{Cd}, \mathrm{Hg}$ and $\mathrm{Pb}$ in blood by ICP-MS for monitoring purposes. Anal methods 2:2049-2054 
8. Dwivedi SK, Dey S (2002) Medicinal herbs: a potential source of toxic metal exposure for man and animals in India. Arch Environ Health 57:229-231

9. Annan K, Dickson RA, Amponsah IK, Nooni IK (2013) The heavy metal contents of some selected medicinal plants sampled from different geographical locations. Pharmacognosy Res 5:103-108

10. Ministry of Health and Welfare Taiwan, Republic of China (2018) Taiwan Herbal Phaemacopeia. 3rd edition.

11. National Pharmacopoeia Committee (2015) Pharmacopoeia of People's Republic of China. 10th edition.

12. The Ministry of Health, Labour and Welfare, the Pharmaceuticals and Medical Devices Agency (2016) The Japanese Pharmacopoeia 17th edition.

13. The Government of the Hong Kong Special Administrative Region. Chinese Medicine Division, Department of Health Hong Kong Chinese Materia Medica Standards (2018) Hong Kong Chinese Materia Medica Standards, Volumes 1-9.

14. World Health Organization (1989) Quality control methods for medicinal plant materials. World Health Organization, Geneva, Switzerland

15. International Organization for Standardization, ISO 18664: 2015 (2015) Traditional Chinese Medicine-Determination of heavy metals in herbal medicines used in Traditional Chinese Medicine.

16. Chen YH, Lu FL, Liu YC, Lo CF (2011) Survey on heavy metals in raw materials of traditional Chinese medicine (VI). Ann Rept Food Drug Res 2:295-308 (Article in Chinese).
17. Chen YH, Lu FL, Liu YC, Lo CF (2011) Survey on heavy metals in raw materials of traditional Chinese medicine (VII). Ann Rept Food Drug Res 2:309-22 (Article in Chinese).

18. Chen YH, Lu FL, Liu YC, Shih YC (2013) Survey on heavy metals in raw materials of traditional Chinese medicine (IX). Ann Rept Food Drug Res 4:228-35 (Article in Chinese).

19. Hsu YH, Chen YHm Lo CF, Lin JH (2007) Survey on heavy metals in raw material of traditional Chinese medicine. Ann Rept BFDA Taiwan R.O.C. 25:127-39 (Article in Chinese).

20. Lai L, Liu FS, Hsu YH, Yu CL, Hsiao SH, Lo CF, Lin JH (2006) Survey on heavy metals in raw material of traditional Chinese medicine (I). Ann Rept BFDA Taiwan R.O.C. 24:228-41 (Article in Chinese).

21. Lai L, Tseng JH, Chen YH, Lo CF, Lin JH (2006) Survey on heavy metals in raw material of traditional Chinese medicine (II). Ann Rept BFDA Taiwan R.O.C. 24:242-256 (Article in Chinese).

22. Lu FL, Chen YH, Huang CY, Lo CF, Lin JH (2008) Survey on heavy metals in raw material of traditional Chinese medicine. Ann Rept BFDA Taiwan R.O.C. 26:112-123 (Article in Chinese).

23. Lu FL, Chen YH, Tseng MC, Lo CF, Lin JH (2009) Survey on heavy metals in raw material of traditional Chinese medicine. Ann Rept BFDA Taiwan R.O.C. 27:51-64 (Article in Chinese).

Publisher's Note Springer Nature remains neutral with regard to jurisdictional claims in published maps and institutional affiliations. 